\title{
A Etapa de Execução da Obra: Um Momento de Decisões
}

\author{
Francisco José de Castro Moura Duarte, D. Sc.
}

Professor Adjunto - Programa de Engenharia de Produção - COPPE/UFRJ

Caixa Postal: 68.507 - CEP: 21.945-470 - Rio de Janeiro - RJ - E-mail: duarte@pep.ufrj.br

Cláudia Vieira Carestiato Cordeiro, M. Sc.

Doutoranda - Programa de Engenharia de Produção - COPPE/UFRJ

Caixa Postal: 68.507 - CEP: 21.945-470 - Rio de Janeiro - RJ - E-mail: claudiac@pep.ufrj.br

\section{Resumo}

O presente artigo apresenta a experiência de intervenção ergonômica na fase de construção do edifício do Centro Integrado de Controle (CIC) de uma indústria petroquímica brasileira, cujo projeto desenvolveu-se com a participação da equipe de ergonomia desde os estudos de base.

Através de uma metodologia apoiada em reuniōes semanais, envolvendo as diferentes equipes participantes deste projeto, conseguiu-se, especialmente, conduzir com sucesso a reconcepção do projeto - fato comum na etapa executiva de uma obra. Os principais fatores que motivaram esta reconcepção foram: a ausência de um projeto executivo; as condições de trabalho no canteiro de obras; a variação constante dos materiais disponíveis no mercado; a descontinuidade das equipes envolvidas; $e$ as indefinições no plano de organização do trabalho.

\section{Abstract}

This paper presents the experience of ergonomic intervention in the construction phase of the Integrated Control Center of a Brazilian petrochemical industry. The project of this building was developed with the participation of the ergonomics team since the preliminary studies.

By means of a methodology based in weekly meetings attend by the various teams taking part in this project, success was met, specially, in the conduction of the reconception of the project - a common situation in a building construction. The main factors that led to this reconception were the absence of an executive project; the working conditions on the work-site; constant variation in materials available on the market; discontinuity of the teams involved and indefinition as to the organized work plan.

Palavras-chave:

Ergonomia, Arquitetura, Projetos Industriais, Espaços de Trabalho.

Keywords:

Ergonomics, Architecture, Industrial Projects, Workplaces.

\section{Introdução: Por Que se Interessar pela Etapa de Construção do Espaço de Trabalho?}

Nosso interesse pela etapa de construção e as reflexões presentes neste artigo têm origem em uma intervenção ergonômica realizada junto ao projeto do Centro Integrado de Controle (CIC) de um refinaria de petróleo brasileira. Esta intervenção teve início no final dos estudos de anteprojeto e se prolongou até o final da construção do novo edifício.

Neste artigo, pretendemos demonstrar que a etapa de execução da obra não consiste exclusivamente na realização do que foi decidido na eta- 
pa precedente e associar este fato a alguns fatores causais.

A idéia central é que pensar a etapa de construção apenas como uma execução de decisões anteriores é supor que tudo foi previsto e que, portanto, a atuação essencial neste período seria assegurar e controlar a conformidade dos trabalhos no canteiro de obras com as especificações do projeto. Esta é uma visão restritiva, uma vez que na etapa de execução muitas decisões ainda são tomadas, com a implicação de diferentes pessoas, de diferentes saberes e especialidades.

A partir deste estudo, concluímos que as decisões tomadas durante a execução dizem respeito não só a aspectos relativos à maneira de realizar os trabalhos, próprias desta etapa. Envolvem também aspectos técnicos e funcionais que vão necessitar de conhecimentos sobre o projeto e a execução da obra, assim como, de conhecimentos relativos ao trabalho a ser realizado nas futuras instalações, especialmente quando o projeto pretende favorecer as necessidades do uso.

Além disto, tais decisões são tomadas em um contexto de fortes restrições financeiras e temporais, marcado por dificuldades de coórdenação de diferentes equipes de trabalho e pelas preocupações com a eficácia técnica do projeto, o que torna a execução uma etapa muito mais complexa do que a princípio se poderia supor. Diante deste contexto, o que foi pensado anteriormente nos projetos pode ser modificado, de acordo com os interesses próprios da etapa de execução, e gerando resultados diferentes daqueles esperados inicialmente.

As decisões que caracterizam a etapa de construção impõem aos diferentes atores expor e negociar suas condições e restrições. Negociar quer dizer aceitar uma parte daquilo que os outros trazem (objetivos e restrições) e aceitar rever e abandonar uma parte de suas posições iniciais. De acordo Bucciarelli (1993), para assegurar a coerência da concepção os atores devem continuamente negociar suas diferenças, construir trocas sensatas e resolver seus diferentes pontos de vis- ta e prioridades. Para esse autor, o processo de concepção é um processo de negociação e de troca.

As reuniões realizadas como parte da intervenção ergonômica, constituíram espaços de troca e situações de comunicação que permitiram a construção de representações semelhantes da futura instalação. A compreensão mútua de objetivos e limitações de cada equipe foram incorporadas à história do projeto, construindo-se uma coerência entre as reconcepções e a proposta original. Sem esta comunicação, os inúmeros cuidados com as necessidades dos usuários durante a concepção do projeto poderiam se perder.

Algumas questões sobre a prática da ergonomia surgiram desta experiência. A literatura dessa área de conhecimento apresenta alguns trabalhos voltados para o desenvolvimento de metodologias que buscam a integração do usuário à equipe de concepção (Daniellou, 1994). Outros se voltam para a compreensão da gestão do canteiro de obras (Six, 1994). E há ainda aqueles que tratam dos problemas de saúde e segurança no trabalho de construção civil (Jong et alii, 1997). A visão global de um projeto e a prática da ergonomia nos conduz a pensar na integração dessas abordagens e a vislumbrar caminhos que precisam ser investigados para a evolução da prática da ergonomia em projetos. Como desenvolver um projeto considerando as condições de trabalho não só dos usuários, mas também dos operários do canteiro? Como incorporar na concepção o saber da execução da obra? Como conduzir as freqüentes reconcepções do projeto?

São estas as questões que tentaremos abordar a partir da experiência deste projeto.

\section{O Projeto do Centro Integrado de Controle}

\subsection{Histórico}

A criação de um novo espaço de trabalho, o Centro Integrado de Controle - CIC, fez parte do 
projeto de mudança tecnológica para o controle da operação dessa refinaria. Para se ter uma idéia da dimensão e do contexto deste projeto citaremos alguns dados e faremos um breve histórico.

Desde o início dos anos 80, a refinaria estudada decidiu pela integração e centralização das salas de controle de suas diferentes unidades de produção, em busca de reduções de custo com mão-de-obra e de maior competitividade. $\mathrm{O}$ contexto econômico nacional Nesta época já se previa a quebra do monopólio do petróleo e a refinaria, uma das maiores e mais antigas do país, necessitava de modernizações para enfrentar a concorrência estrangeira.

Os estudos de viabilidade realizados neste período tinham uma forte preocupação em realizar um projeto adequado às necessidades específicas da operação, dando condições de segurança e confiabilidade à operação. Tais preocupações se justificavam, em primeiro lugar, por causa dos riscos de acidentes graves e explosões, inerentes a este processo de produção. E em segundo lugar, porque a centralização e integração de salas de controle no Brasil era, e ainda é, uma mudança tecnológica recente, iniciada de fato por volta dos anos 90. Esta mudança se iniciou em meio a uma realidade de refinarias grandes e antigas, cujas as unidades poderiam estar distantes do centro de controle cerca de $2 \mathrm{~km}$, o que faz do tornava o processo de centralização uma coisa nova e complexa para a maioria dos envolvidos.

Neste caso, tratava-se de uma refinaria de grande complexidade, com 28 unidades dedicadas à produção de combustíveis e lubrificantes, diversas instalações de apoio (utilidades) e previsão para mais 4 novas unidades no setor de combustíveis ${ }^{1}$, distribuídas em uma área de total de 10 $\mathrm{km}^{2}$. Na época, a empresa possuía cerca de 1.800 empregados diretos, sendo $60 \%$ trabalhadores de turno dedicados ao controle das instalações.

Durante os estudos de viabilidade, questionouse Devido a este contexto, discutiu-se por um longo período as vantagens e desvantagens da centralização da operação, a forma como ela se daria (em um ou vários centros integrados), o limite de efetivos para uma operação segura, a polivalência entre operadores e a tecnologia a ser implantada.

Somente em 1994 a decisão de investimento foi tomada, com a definição pela construção de um único edifício, onde funcionaria o CIC, centro, agrupando o controle de todas as unidades produtivas e sistemas de utilidades. Estes passariam a operar através uma nova tecnologia: os Sistemas Digitais de Controle Distribuído (SDCD). Até este momento, a maior parte das unidades operava através de painéis analógicos em salas de controle locais, situadas em cada unidade.

Somente cerca de 3 unidades já começavam a operar em paralelo através do SDCD.

O envolvimento da Equipe de Ergonomia do Programa de Engenharia de Produção da COPPE/ UFRJ no projeto de modernização tecnológica desta refinaria iniciou-se em 1990. Dois eventos, ocorridos em momentos distintos, marcaram este envolvimento.:

Em 1990, foi iniciada uma pesquisa de campo para tese de doutorado (Duarte, 1994) que abordava a organização de trabalho ou mais especificamente o dimensionamento das equipes de turno face à centralização e integração das salas de controle. Durante a realização dessa tese foram realizadas visitas à situações de referência no Brasil (refinarias em outros estados) e no exterior (usina petroquímica da Rhône Poulenc, que havia passado por modernização tecnológica similar à pretendida pela empresa estudada). Esta tese de doutorado foi concluída em abril de 1994.

Mais recentemente, em março de 1995 e em julho de 1996, foram firmados dois contratos de assessoria, através da Fundação COPPETEC. Trataremos aqui da atuação da equipe de ergonomia no projeto CIC neste segundo momento

1. Dados do final de 1997, época em que se encerrou nosso contrato. 
(1995 a 1997), com ênfase nas questões relativas ao espaço de trabalho.

O primeiro contrato, ao qual chamaremos Fase 1 , contemplou a intervenção na etapa de concepção, envolvendo a concepção do espaço, de softwares e a organização do trabalho. Com relação ao ambienteespaço de trabalho, foram realizados os anteprojetos de layout, iluminação e acústica da sala de controle do CIC, além de novas visitas à situações de referência, incluindo a refinaria da Antuérpia, na Bélgica.

O segundo contrato, Fase 2, deu continuidade aos trabalhos iniciados no contrato anterior e, em relação ao projeto do espaço, contemplou o acompanhamento da etapa de execução da obra do novo edifício.

\subsection{Demandas, Metodologias \\ e Resultados de Cada Fase}

\subsubsection{Fase 1}

\subsubsection{Demanda}

A intervenção ergonômica no projeto do CIC (mar/95) foi motivada por uma questão relativa ao espaço de trabalho. A empresa contratada para concepção do projeto do novo edifício (empresa 1) havia falido e a refinaria solicitou à equipe de ergonomia uma análise do material já elaborado (anteprojetos de arquitetura e estrutura) para decidir como daria continuidade ao projeto. Uma das premissas adotadas pela empresa era realizar

A Fig. 1, a seguir, esquematiza a participação das diversas equipes nas diferentes fases do projeto do novo espaço de trabalho:

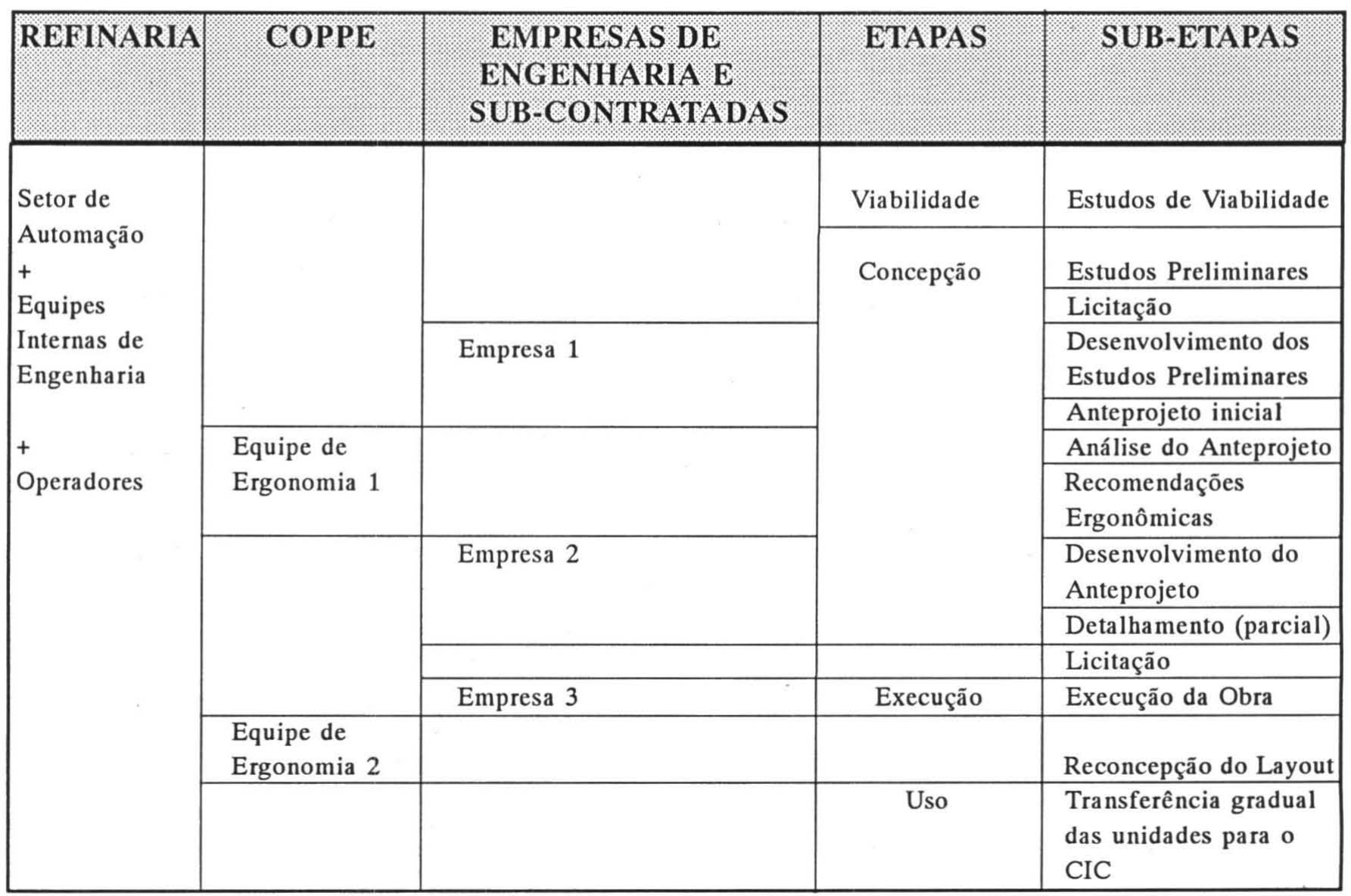

Fig. 1: Participação das equipes nas etapas do projeto do espaço 
um projeto adequado à operação e a idéia neste momento era aproveitar os anteprojetos realizados pela empresa 1, contratando nova firma para dar continuidade ao seu desenvolvimento.

Posteriormente, a demanda se estenderia para a concepção da organização do trabalho de operação e para a configuração de telas do Sistema Digital de Controle Distribuído - SDCD. ${ }^{2}$

\subsubsection{Metodologia}

A avaliação do projeto inicial foi feita por uma equipe de três ergonomistas (equipe 1). O referencial teórico metodológico adotado foi a Análise Ergonômica do Trabalho - AET (Wisner, 1988; Guerin et alii, 1991), onde a partir de um diagnóstico das condições de trabalho é possível fazer recomendações para a adequação dos meios de trabalho às necessidades da operação.

Inicialmente foi feita uma macroanálise da situação de trabalho, enfocando principalmente as seguintes características:

- Funcionamento da refinaria (tipos de unidades de produção e interdependência entre elas);

- População de trabalhadores (tempo de serviço e absenteísmo); e

- Repartição de tarefas entre os operadores de sala de controle e de campo.

Após este levantamento, foram realizadas $o b$ servações gerais e entrevistas em cada uma das unidades de produção, com o objetivo de identificar as comunicações entre elas e assim poder ter elementos que auxiliassem à decisão de como agrupar os postos de trabalho na sala de controle do CIC.

Paralelamente, foram checadas as condições de trabalho em outras refinarias que já haviam adotado a nova tecnologia e passado pela mesma situação de transição, através de visitas a situações de referência (Daniellou, 1992).

Posteriormente, foram realizadas as análises da atividade dos operadores das unidades de destilação e de craqueamento catalítico, primeiras unidades que deveriam migrar para o CIC. As análises em diferentes situações de trabalho (partida, parada e incidentes) nestas duas unidades produtivas possibilitaram recomendações mais precisas em termos da necessidade de consoles e de espaços para sistemas de comunicação e terminais de computadores dos sistemas de controle avançado, como veremos a seguir.

Para a definição de uma nova proposta de layout foram realizadas diversas reunióes envolvendo operadores, engenheiros e ergonomistas. Nessas reuniões de trabalho, relatadas por Lima (1999), foi utilizada uma maquete da futura sala de controle, com todas as peças móveis, de forma a permitir reorganizações do layout (Maline, 1994).

As recomendações ergonômicas foram apresentadas à empresa sob forma de relatório e desenhos a nível de estudo preliminar. Estas recomendações basearam-se nos resultados da análise do trabalho; na experiência dos integrantes da equipe em intervenções ergonômicas já realizadas em projetos similares; nas recomendações constantes da literatura internacional sobre projeto de salas de controle e nas recomendações das normas (nacionais e internacionais) relativas ao projeto de ambientes de trabalho - em especial, o projeto da norma ISO 11.064 - Ergonomics Design of Control Centers.

Esse material foi encaminhado pela refinaria à segunda empresa de engenharia (empresa 2), contratada para dar prosseguimento ao desenvolvimento do projeto.

\subsubsection{Resultados}

Os principais resultados da avaliação realizada pela equipe de ergonomia foi a redefinição do layout proposto no anteprojeto inicial de arquitetura e a alteração do número de consoles de

2. Para maiores detalhes sobre o trabalho realizado em relação à organização do trabalho, ver Goldenstein, 1997; e sobre a configuração de telas, ver Santos, 1998. 
SDCD previstos para a operação de cada unidade de produção. Além disto, foram propostas alterações nos projetos de iluminação, acústica, refrigeração e revestimento dos diversos ambientes que compunham o projeto arquitetônico inicial.

$\mathrm{O}$ objetivo principal das mudanças sugeridas foi adequar o ambiente de trabalho às necessidades reais da atividade dos operadores, respeitando todavia os objetivos e as limitações colocadas pelo setor de automação da refinaria, os quais não permitiam alterar os anteprojetos existentes (arquitetura e estrutura) no que diz respeito ao dimensionamento dos espaços. Ou seja, as mudanças sugeridas tiveram que adaptar-se à definição de áreas e volumes do anteprojeto de arquitetura, só sendo possível pequenas alterações, como por exemplo, os espaços delimitados por divisórias móveis.

Seguem as alterações sugeridas e realizadas:

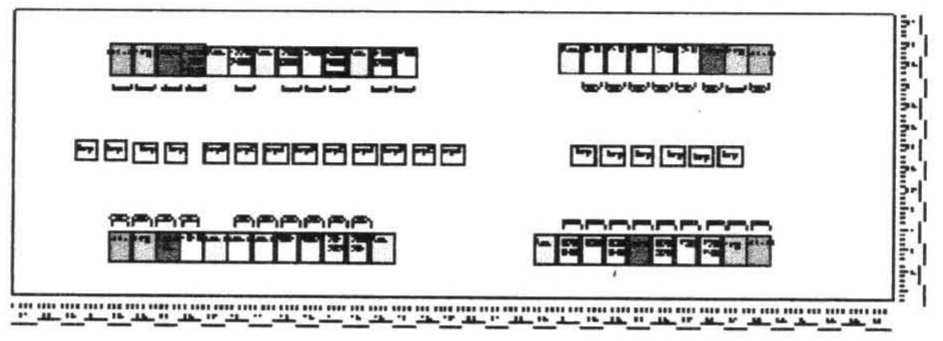

Fig. 2: Layout inicial

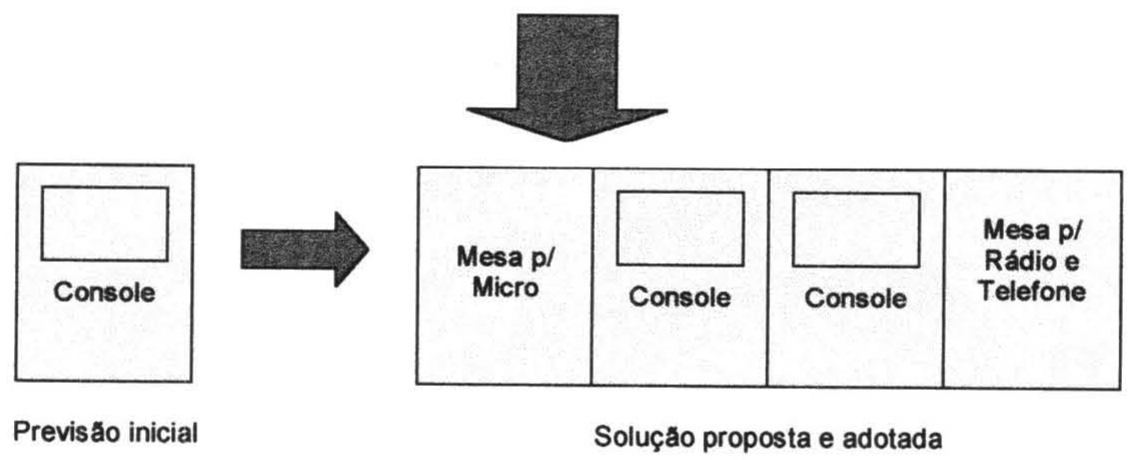

Fig. 3: Alteração do módulo básico de operação
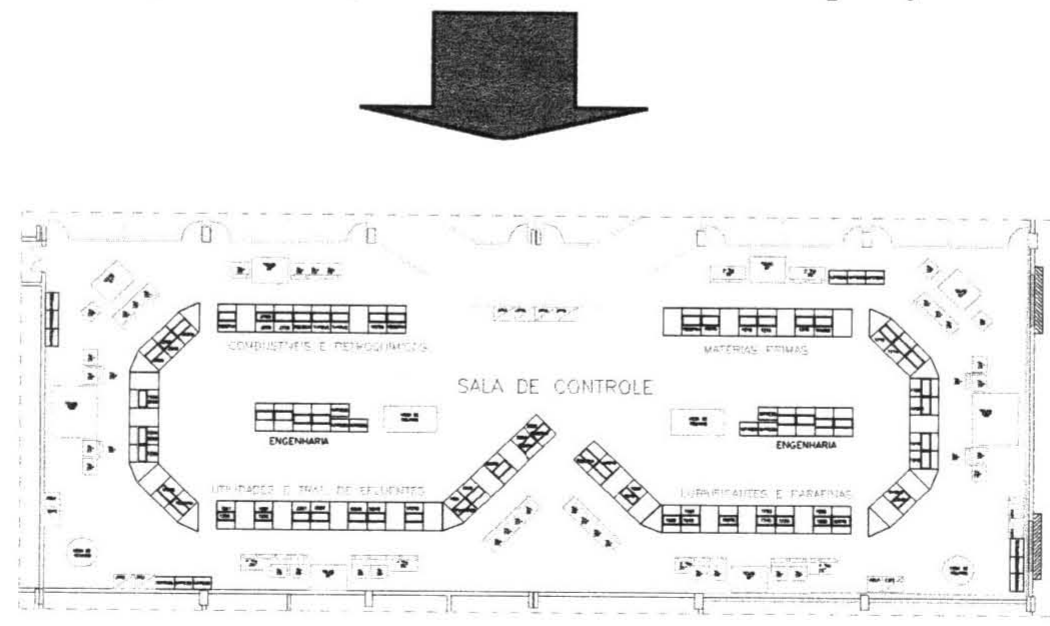

Fig. 4: Layout - Fase 1 
- O módulo básico de operação foi redefinido em função das necessidades de cenários vistos na análise da atividade (paradas de manutenção, partidas, incidentes, ...), quando mais de um operador é necessário para controlar o processo. Além disto, o novo módulo passou a prever espaços para um microcomputador, que abrigaria no futuro um sistema de controle avançado que estava sendo projetado, e para o apoio do sistema de comunicação com a área (rádio e telefone).

- O layout linear inicial transformou-se em um layout de ilhas, buscando aproximar as unidades que se comunicavam com frequêencia e privilegiando o agrupamento de unidades com processos similares.

- Foram especificados materiais para composição e acabamento de piso, paredes, divisórias e teto, de forma a atender as necessidades acústicas e lumínicas da sala de controle. O esquema de placas do piso e do teto foram refeitos com este objetivo.

- Em termos acústicos, foi também sugerido a utilização de um sistema eletrônico de mascaramento para garantir a comunicação entre operadores próximos e a privacidade entre operadores distantes, visto que o grau de concentração dos operadores de cada área não deveria ser perturbado por ruídos e pela conversação dos operadores das outras unidades. Além disto, a perfeita comunicação de códigos numéricos (ligada à inteligibilidade da fala) deveria ser assegurada durante a operação.

- Em termos de iluminação, buscou-se ainda introduzir a iluminação natural na sala de controle através da aberturas de janelas e da criação de um jardim de inverno. O objetivo foi reduzir a sensação de confinamento e criar um referencial de tempo e condições meteorológicas para os operadores (o que favorece a auto-regulação do organismo). Procurou-se, também, minimizar os ofuscamentos e reflexos sobre as telas de operação, reposicionando-se luminárias e criando-se uma camada de placas suspensas no teto (baffles) que evitariam a incidência direta dos raios luminosos sobre as telas.

\subsubsection{Fase 2}

\subsubsection{Demanda}

Em novembro de 1996, a equipe de ergonomia iniciou o acompanhamento da execução da obra do edifício do CIC, já parte de um novo contrato. O objetivo inicial da refinaria era buscar a antecipação dos problemas que pudessem surgir nesta etapa e que fossem desfavoráveis aos objetivos iniciais do projeto. Com isto, pretendia-se que soluções fossem dadas em tempo hábil e que

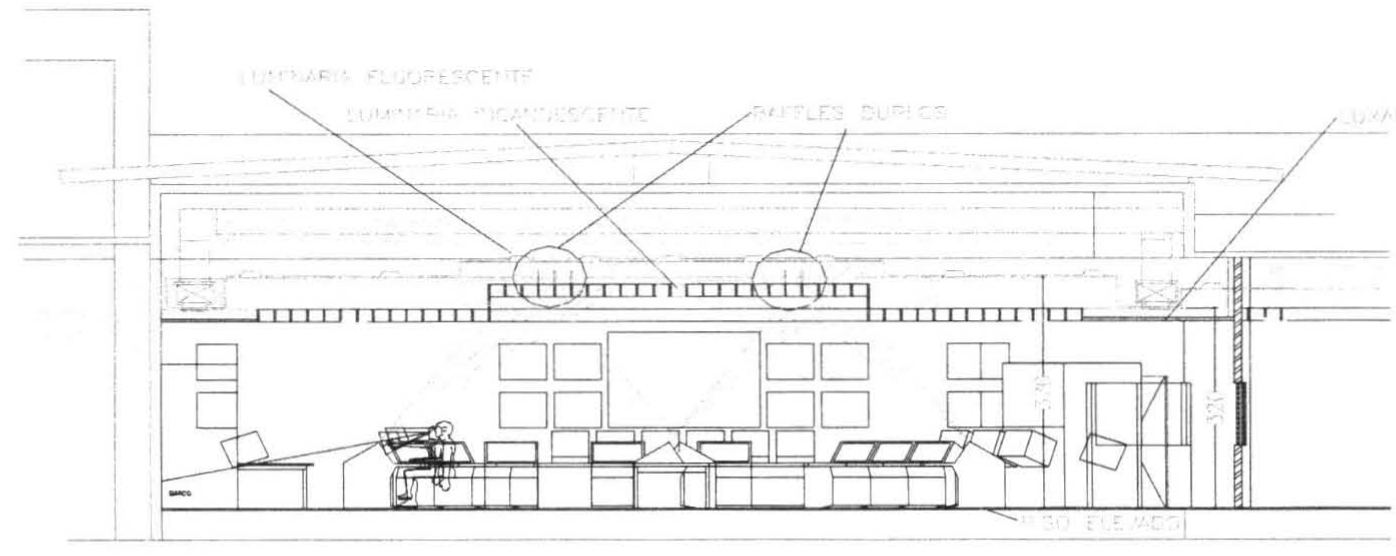

Fig. 5: Corte esquemático 
não se opusessem à eficácia e à confiabilidade da atividade futura de trabalho, principal premissa da etapa de concepção.

Dentro deste espírito, a equipe de ergonomia $2^{3}$, passou a atuar em colaboração com o setor de automação da empresa e com as demais equipes envolvidas com a execução da obra, auxiliando nas tomadas de decisão relativas às modificações e adaptações nos projetos; checando as interferências com o resultado final e procurando compatibilizar essas alterações com os objetivos da concepção.

Durante a vigência deste contrato, alterações organizacionais na empresa levaram à principal alteração de projeto ocorrida durante a obra: a reformulação do layout proposto para a sala de controle com revisão da disposição e do compartilhamento dos consoles de SDCD.

\subsubsection{Metodologia}

Para esta fase, instituiu-se um esquema de reuniões periódicas e visitas à obra, com a participação das equipes envolvidas com a construção do CIC. Foram realizadas 35 reuniões, onde prevaleceram os assuntos relativos à obra.

Com a necessidade de alteração do layout, adotou-se também um esquema paralelo de reuniões para a reformulação do layout, porém, com características e objetivos diferentes das primeiras. Como as alterações no layout se refletiam diretamente na obra, algumas reuniões de obra trataram dos dois assuntos devido à inter-relação dos temas ${ }^{4}$. Para a alteração do layout, houveram 9 reuniōes específicas, perfazendo um total de 44 reuniões realizadas no período de dezembro de 1996 a julho de 1997. As reuniões para reconcepção do layout ocorreram, na maior parte das vezes, de forma intercalada às reuniões de acompanhamento da obra. Para melhor compreensão, descreveremos adiante os dois tipos de reunião em itens diferentes.

Foi ainda realizado um aprofundamento do estudo sobre comunicação entre setores, onde verificou-se que a necessidade de comunicação se dava principalmente pela interdependência de processos produtivos.

A documentação do trabalho realizado foi feita através de relatórios parciais entregues mensalmente ao Setor de Automação, contendo: a avaliação do andamento dos trabalhos naquele mês (obra e layout); a previsão do que seria tratado no mês seguinte; e a cópia de todas as atas e registros escritos do período.

Ao término do contrato, foi elaborado um relatório final contendo: a descrição e a avaliação dos trabalhos realizados (obra e layout); as pendências a serem resolvidas pela empresa após o término do nosso contrato; as cópias de todas as atas, registros, anotações, documentos e desenhos utilizados e gerados durante o contrato; e as principais recomendações e os recursos disponíveis para uso do espaço (a serem divulgados pela refinaria para os operadores). O objetivo deste relatório foi fazer com que a empresa tivesse uma documentação detalhada de todo o trabalho realizado, de forma que a história deste projeto pudesse ser consultada nas futuras e inevitáveis alterações por que passam os ambientes de trabalho ao longo do tempo.

\section{As reuniōes de acompanhamento da obra}

Nas primeiras reuniões para acompanhamento da obra, o setor de automação da refinaria e a equipe de ergonomia apresentaram os principais conceitos

3. Nesta época, a parte da equipe de ergonomia que se dedicava ao projeto do espaço era formada por dois ergonomistas, sendo um deles membro da equipe de ergonomia inicial.

4. Por exemplo: As alterações sucessivas sobre o projeto do layout, que ocorriam durante a execução da obra, originaram reformulações no projeto de iluminação da sala, visto que este previa uma série de recursos para evitar os reflexos nas telas de operação. Quando um console passava a ocupar uma posição onde anteriormente não estava prevista a existência de uma tela, como a posição de uma mesa de apoio para rádio e telefone, tornava-se necessário um checagem do posicionamento das luminárias e a sua correção. 
e objetivos do Projeto CIC, à empresa de engenharia contratada para a construção do novo edifício (empresa 3), o que foi feito a partir das características da atividade dos operadores em salas de controle. Uma destas reuniões foi documentada em vídeo pelo setor de automação, para que outras pessoas que viessem a participar deste processo, no futuro, pudessem recorrer a esta fita para conhecer as preocupações iniciais pertinentes ao projeto.

A seguir, organizou-se o esquema de reuniões semanais entre as equipes envolvidas nesta etapa, que reuniam representantes:

- Do setor de automação da refinaria - responsável pelo Projeto CIC;
- Do setor de engenharia da refinaria - responsável pela fiscalização da execução da obra;

- Da empresa de engenharia contratada para a construção do CIC (empresa 3) e das suas subcontratadas (instalação de ar condicionado, montagem do forro, piso elevado,...); e

- Da equipe de ergonomia.

Algumas destas reuniões contaram ainda com a participação de fornecedores de materiais e representantes da equipe de concepção do projeto (membros da equipe técnica da refinaria e membros da empresa de engenharia contratada para desenvolvimento do projeto - empresa 2). A Fig. 6 apresenta os principais atores envolvidos nas reu-

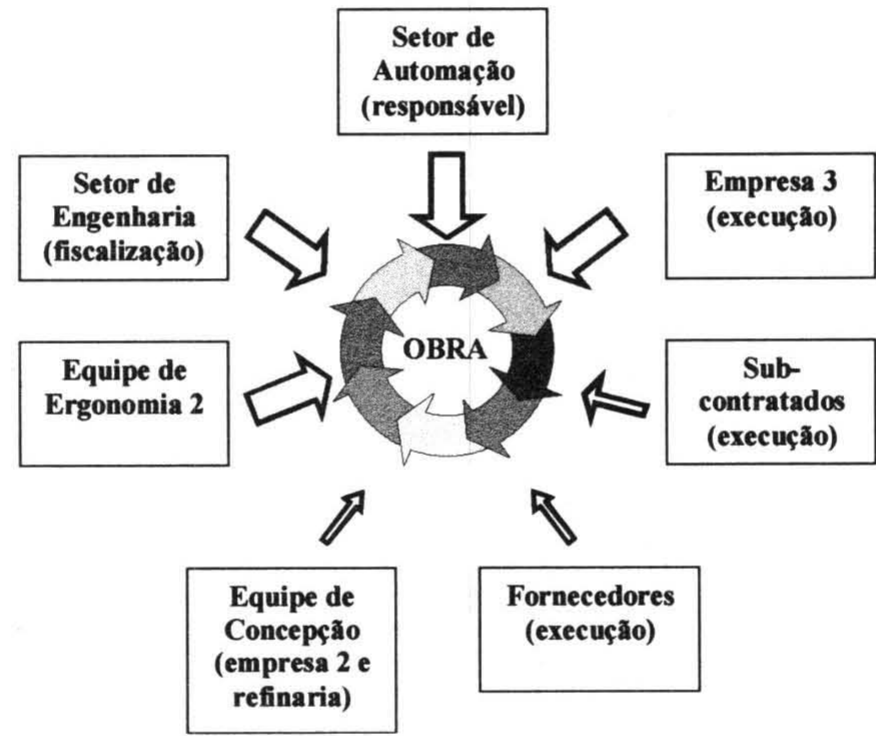

Fig. 6: Participação das diversas equipes nas reuniões de obra

niões de acompanhamento da construção do CIC.

Os objetivos desta dinâmica foram antecipar e compartilhar os problemas das diversas equipes $\mathrm{e}$ negociar soluções que mantivessem o equilíbrio entre os interesses e as necessidades de todos os envolvidos.

Após as reuniões, eram realizadas visitas à obra onde verificava-se as pendências e o andamento das soluções propostas. Conforme a fase da execução, o número de reuniões e visitas à obra se intensificou atendendo às necessidades do seu andamento.

Para todas as reuniões de acompanhamento da obra foram elaboradas registros escritos (atas), cujas cópias eram distribuídas a todos os participantes e que serviam de apoio para a reunião seguinte. No início de cada reunião, a ata da reunião anterior era checada para se verificar as pendências existentes e o andamento das soluções propostas. A responsabilidade pela elaboração das atas ficou a cargo da equipe de ergonomia após decisão conjunta dos participantes.

As reuniões para reformulação do layout

As reuniões de layout foram similares às reuniões que ocorreram durante a análise do anteprojetos de arquitetura e estrutura (Fase 1), com características 
próximas às reuniões de simulação do trabalho descri- de automação da refinaria e da equipe de ergonomia tas por Maline (1994). Houve a participação dos ope- (Fig. 7).

radores (futuros principais usuários do CIC), do setor Como suporte para a interação destes atores

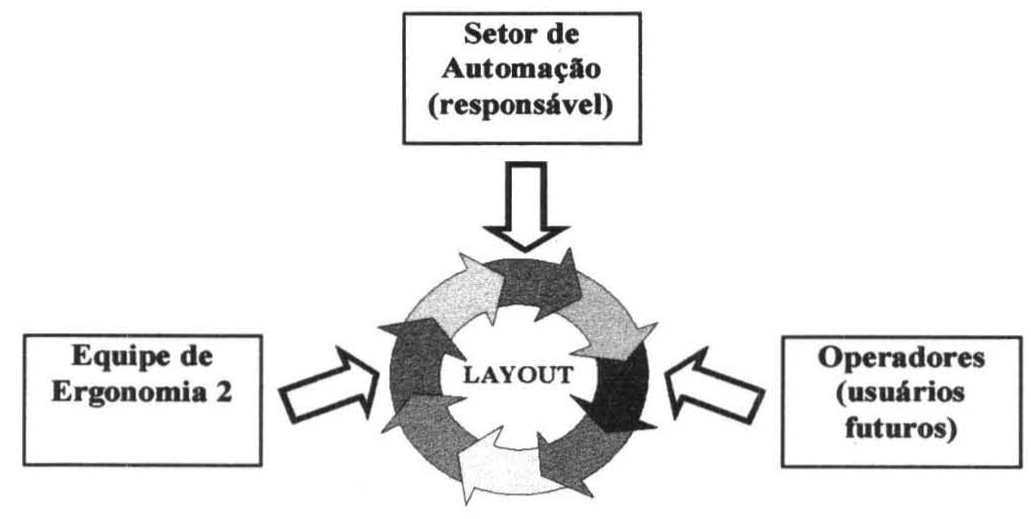

Fig. 7: Participação das diversas equipes nas reuniões de reformulação do layout

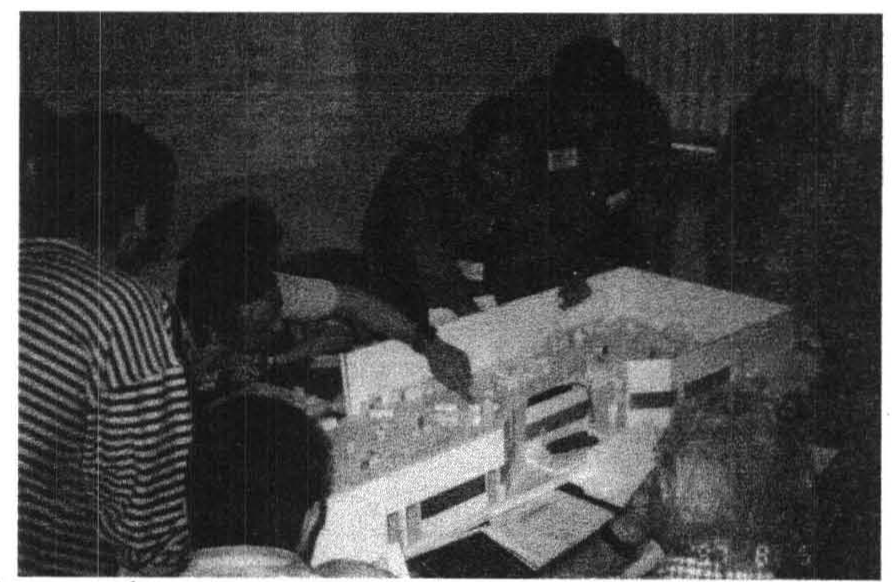

Fig. 8: Utilização de maquete e plantas para discussão das propostas (simulação)

foram utilizadas plantas e maquete da sala de controle do CIC (Fig. 8).

Estas reuniões foram gravadas em fitas $\mathrm{K} 7 \mathrm{e}$ as alterações de layout propostas pelos operadores na maquete foram registradas em esquemas sobre plantas baixas pela equipe de ergonomia.

Como as alterações do layout se prolongaram até o término da obra, foi possível realizar uma última reunião de simulação na própria sala de controle, com a marcação das posições das consoles em escala real, no chão.

\subsubsection{Resultados}

A dinâmica de reuniões implementada para o acompanhamento da obra permitiu a antecipação de problemas da execução e as tomadas de decisão coletivas, a partir da discussão dos diversos pontos de vista dos participantes.

A partir das reuniões, foi possível compatibilizar os diversos projetos complementares com o projeto de arquitetura, assim como, desenvolver e redefinir uma série de soluções adotadas no projeto inicial, mantendo a coerência com as necessidades dos usuários, como por exemplo: a alteração de detalhes para as montagens de divisórias, piso e teto (diretamente ligados às condições lumínicas e acústicas da sala); o posicionamento das bocas de insuflamento de ar condicionado; a substituição de materiais especificados; a escolha do sistema de controle de entrada e saída de pessoas na sala; modificação dos vãos 
de abertura do jardim de inverno (aumento da iluminação natural); dentre outros relacionados com a atividade futura.

Em relação ao layout, foi possível reformular a disposição, o número e o compartilhamento de consoles em função do novo plano organizacional da empresa ${ }^{5}$, mantendo-se os critérios adotados na etapa anterior (Fase1). Com o aprofundamento do estudo realizado, obteve-se uma melhor compreensão das necessidades de comunicação verbal e visual entre as unidades. Como conseqüência, a lógica de agrupamento dos consoles, que inicialmente favorecia somente a similaridade de processos, passou a contemplar mais dois aspectos: a proximidade geográfica das unidades e a interdependência de processos (Fig. 9).

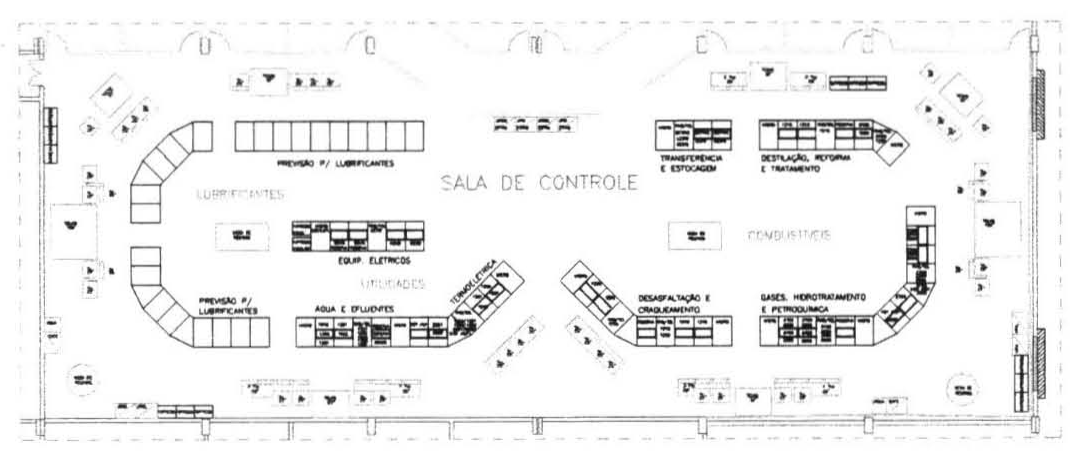

Fig. 9: Layout - Fase 2

\section{A Reconcepção do Projeto Durante a Execução}

Durante a fase de execução de uma obra, vários aspectos do projeto são revistos e reconcebidos. Tais aspectos podem ser pequenos detalhes, como a substituição de materiais especificados por materiais considerados similares ou simplificações de detalhes construtivos para facilitar a montagem. Porém, a soma de pequenas alterações, ou mesmo uma única simplificação, poderá vir a comprometer o resultado esperado em projeto.

É importante frisar que não queremos aqui responsabilizar a equipe de execução pelos resultados negativos ou inesperados de um projeto. Não se trata de encontrar culpados, e sim de compre- ender o que leva a esta reconcepção e como ela se dá.

Sabemos que muitas vezes a equipe de concepção desconhece como um detalhe será executado, ignorando as condições de trabalho do canteiro (Béguin e Bergamini, 1996). Por outro lado, a mudança constante de materiais disponíveis no mercado e a alta rotatividade da mão-de-obra no canteiro torna difícil antecipar todas as necessidades e limitações da equipe de execução, já que a variabilidade de condições de trabalho e mão-deobra é extrema e constante não só de uma obra para outra, como durante a própria obra.

Paralelamente, as necessidades da empresa que contrata a concepção de um novo espaço de trabalho vão evoluindo e atualmente se modificam rapidamente. Este processo constante de adapta-

5. A mudança organizacional foi influenciada por diversos fatores internos a empresa. As unidades que inicialmente era agrupadas em 4 setores passaram a ser agrupadas em 3 setores. Este reagrupamento levou em consideração os resultados obtidos no estudo ergonômico que identificaram 3 lógicas predominantes para agrupamento das unidades: proximidade geográfica, similaridade de processos e interdependência de processos.

Neste momento, a empresa questionava-se sobre a continuidade dos processos de fabricação de lubrificantes. Observa-se no layout, que a ocupação dos consoles de operação deste setor ficaram em aberto, para adequar-se pgsteriormente às decisões gerenciais da refinaria. 
ção da empresa às condições do mercado é por vezes mais rápido que o processo de produção de um novo edifício. Assim, os dados considerados no início do projeto podem já não ser válidos no momento da execução, o que leva a alterações no projeto.

A reconcepção se dá então pela conjunção de diversos fatores e é composta não só de mudanças e ajustes no que foi proposto em projeto, mas também do desenvolvimento de idéias que ainda não foram completamente definidas pela equipe inicial de concepção.

No caso estudado, a reconcepção do projeto na etapa de execução envolveu deste as alterações de especificações de acabamentos diversos até a redistribuição do layout dos consoles, passando por outras alterações de grande porte como o reprojeto do teto e a abertura de vãos de iluminação no jardim de inverno.

\subsection{Os Fatores que Levaram à Reconcepção}

Os fatores que levaram à reconcepção do projeto, neste caso, nos mostram como um projeto pode ser influenciado por questões organizacionais e político/econômicas, além das questões técnicas intrínsecas ao processo.

\subsubsection{A Ausência de um Projeto de Execução}

A obra em questão foi executada com base em desenhos com diversos níveis de detalhamento. A maior parte dos desenhos estava a nível de anteprojeto e alguns encontravam-se em escala reduzida para a execução e sem nenhum detalhamento. Outros eram em parte detalhados. Encontramos várias incompatibilidades entre plantas, seja do mesmo projeto ou de projetos complementares e também incompatibilidades entre os desenhos e o caderno de especificações. Isto demonstra que o trabalho de compatibilização de projetos foi realizado superficialmente ou não foi realizado.
Considerar este fato como uma questão somente de competência das equipes envolvidas seria simplificá-la. Acreditamos que, em parte, este problema pode ocorrer devido a falhas na formação dos projetistas e a sua pouca experiência em obras. Porém, outros fatores são tão importantes quanto este para que se tenha um projeto de execução com qualidade. E o principal deles é que a empresa contratante reconheça a necessidade deste serviço e o contrate com remuneração e prazo compatíveis com o trabalho a ser desenvolvido, o que não aconteceu neste caso.

Cabe aqui questionarmos se um projeto de execução de boa qualidade evitaria a reconcepção do projeto no canteiro de obras. Acreditamos que não, pois como veremos a seguir existem outros fatores que levam à reconcepção e dificilmente se poderia prever a forma exata como todas as atividades do canteiro serão desenvolvidas. Muitas idéias previstas em projeto só são detalhadas durante a execução, conforme o edifício vai tomando forma ou conforme a necessidade da própria execução. Porém, se este trabalho de compatibilização entre projeto de arquitetura e projetos complementares houvesse sido realizado, vários problemas surgidos na obra teriam sido antecipados.

Os problemas ocorridos durante a montagem do teto da sala de controle exemplificam claramente a importância da compatibilização de projetos e do acompanhamento da execução da obra:

A complexidade da montagem dos forros originou-se em uma limitação inicial colocada pela refinaria, em relação à modificação da altura entre a laje e o piso (pé-direito), considerada baixa desde a análise do anteprojeto inicial. Devido ao investimento já realizado com os anteprojetos de arquitetura e estrutura, a refinaria optou por não alterá-la, pois a alteração iria gerar mudanças no cálculo estrutural.

Para superar esta limitação e atender às necessidades lumínicas e acústicas da sala, foi necessário lançar mão de uma solução bastante complexa. O teto seria revestido por duas camadas de 
forro, uma camada mais alta formada por placas de material absorvente acústico (lã de vidro), onde as luminárias ficariam embutidas; e uma camada mais baixa, composta por painéis verticais suspensos (baffles) que evitariam o reflexo das lâmpadas sobre as telas e complementariam o índice de absorção acústica necessário ao uso da sala.

Como a altura da laje era pequena e as vigas que a sustentavam muito altas (1,00 m de altura), tornou-se necessário desnivelar estas camadas de forma a embutir a tubulação de ar condicionado na periferia da sala, mantendo o pé-direito central mais elevado.Este recurso visava a redução da sensação de achatamento que um pé-direito muito baixo ocasionaria em uma sala tão ampla.

No período da obra, durante cerca de um mês, foi necessário que a equipe de ergonomia desenvolvesse a compatibilização entre os projetos de arquitetura, estrutura, acústica e ar condicionado com o projeto de iluminação. O projeto de iluminação foi praticamente refeito em função de uma série de divergências entre os demais projetos e novas solicitações da refinaria (modulação específica do forro, colocação de baffles nas salas anexas, alterações do layout dos consoles,...). Tais solicitações não haviam sido feitas à empresa contratada para o desenvolvimento do detalhamento do projeto (empresa 2). Foram feitas posteriormente à empresa 3 (construtora), durante as reuniões de acompanhamento da obra, gerando uma série de adaptações na etapa construtiva.

Mesmo assim, devido a complexidade da solução, ocorreram problemas na execução, ligados a erros na altura da montagem da tubulação de ar condicionado (montados abaixo do previsto), na altura da montagem do forro (diferença nos desníveis) e na compra de materiais (as lâminas dos baffles foram compradas maiores, pela cota de eixos, não descontando o espaçamento necessário para montagem).

Assim, o projeto de iluminação, já alterado durante a execução para incorporar as novas exigências da empresa, foi mais uma vez recon- cebido, agora durante a montagem do forro, mediante o compromisso entre as equipes de se fazer um ajuste final no posicionamento das luminárias, depois da colocação dos consoles do SDCD em sua posição final, a fim de se evitar reflexos na tela de operação (uma das premissas do projeto).

Outro aspecto a ser considerado no projeto de execução é a compreensão das informações que constam nos desenhos, pois nem sempre o que está claro para quem projetou é compreendido com clareza por quem vai executar. O erro na compra dos baffles originou-se na interpretação errada dos desenhos.

Além deste tipo de dificuldade, cada empresa subcontratada para a execução de determinados serviços, só recebe os desenhos da parte do projeto que lhe diz respeito e pode não compreendêlo totalmente. Uma das origens da necessidade de se reprojetar o acabamento do teto foi esta. Em determinada reunião, foi verificado que os desenhos de arquitetura e do projeto de ar condicionado não mostravam os diversos desníveis e camadas de acabamento do teto, embora houvesse um desenho do estudo ergonômico detalhando a solução. Mais tarde, verificamos que a equipe que desenvolveu o projeto do ar condicionado só havia recebido os desenhos do anteprojeto de arquitetura, sem os detalhes. Como esses desenhos eram em escala reduzida, o acabamento do teto era representado apenas por uma linha, dando a impressão que o forro seria uma camada única nivelada. O detalhe do estudo ergonômico não foi enviado, nem mencionado neste desenho de arquitetura, embora somente neste detalhe estivesse explícito que o forro seria em duas camadas cada uma com três desníveis.

Estes exemplos nos mostram que, embora não se possa antecipar completamente o futuro e prever todos os problemas que surgirão no decorrer de uma obra, a compatibilização de projetos e o detalhamento que compõem um projeto de execução, conseguem dar conta de uma série de problemas e evitam diversas adaptações feitas no 
canteiro de forma limitada, sem um prazo adequado, já que a solução durante a obra é dada muitas vezes com o material comprado e a mãode-obra já contratada.

\subsubsection{As Condições de Trabalho no Canteiro de Obras}

A equipe de execução do CIC era formada por uma equipe básica da construtora (empresa 3) e diversas equipes subcontratadas por esta para a prestação de serviços. Todos buscando atuar como uma única equipe de execução. Esta estrutura é bastante comum no setor de construção civil, e dela decorrem alguns aspectos da variabilidade das condições de trabalho encontradas num canteiro de obras.

O canteiro de obras é um setor de produção onde a variabilidade é extrema e constante. Tudo é variável: o espaço de trabalho vai se alterando durante a obra; as condições do tempo podem definir se uma atividade vai ser realizada ou não na data prevista; o fornecimento de materiais muitas vezes não corresponde ao planejado, pois não se costuma trabalhar com estoques; as equipes são alteradas a cada etapa construtiva, sendo mínimo o número de trabalhadores que permanecem na obra do início ao fim; a colaboração entre estes trabalhadores tem que ser construída a todo momento, pois as equipes se modificam não só durante a obra, mas também de uma obra para outra; enfim, cada momento de uma obra sempre terá características que lhe serão peculiares.

Por outro lado, o trabalho realizado pelas diversas equipes que atuam na construção têm como premissas o atendimento ao prazo e ao custo estipulados em contrato, além do compromisso com qualidade técnica da obra, normalmente esperada. Estes fatores constituem as principais restrições que guiam as tomadas de decisão no canteiro e, assim, a reconcepção do projeto, , passa a ser orientada pela lógica de cumprimento de prazos, de custos pré-fixados e de qualidade, advinda da responsabilidade técnica, enquanto a concepção inicial foi orientada para as necessidades do usuário. Estas lógicas, embora a princípio não sejam necessariamente conflitantes, podem originar decisões contraditórias entre a concepção inicial e as suas transformações durante a execução.

Finalmente, outro aspecto que leva à reconcepção é o desconhecimento, por parte da equipe inicial de concepção (incluindo arquitetos, engenheiros, ergonomistas e operadores), do conteúdo do trabalho dos operários das diferentes equipes de montagem e das condições de realização desse trabalho, o que gera a necessidade de alterações nos detalhes construtivos para facilitar, ou até mesmo permitir, a montagem.

Voltando ao exemplo da montagem do teto,

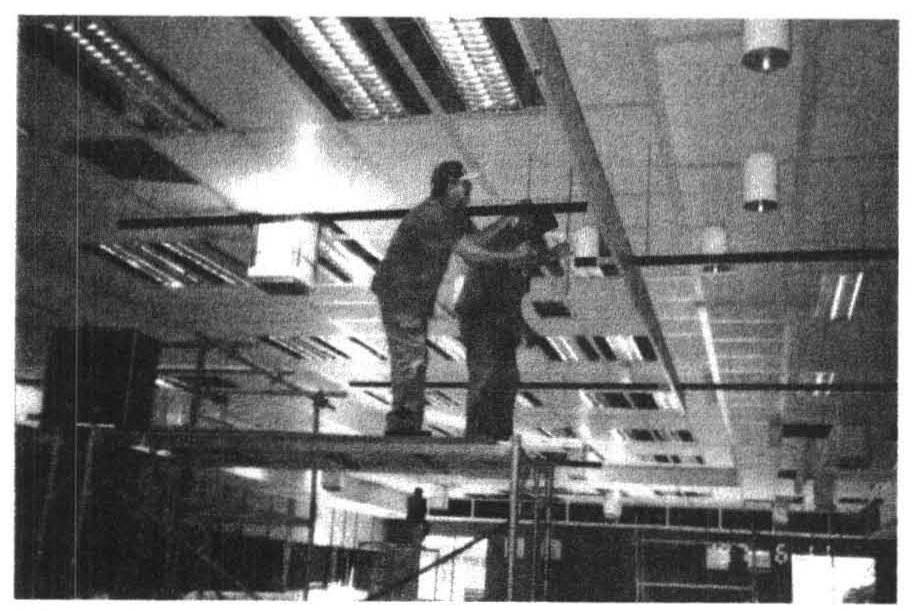

Fig. 10: Montagem do teto - Colocação dos baffles 


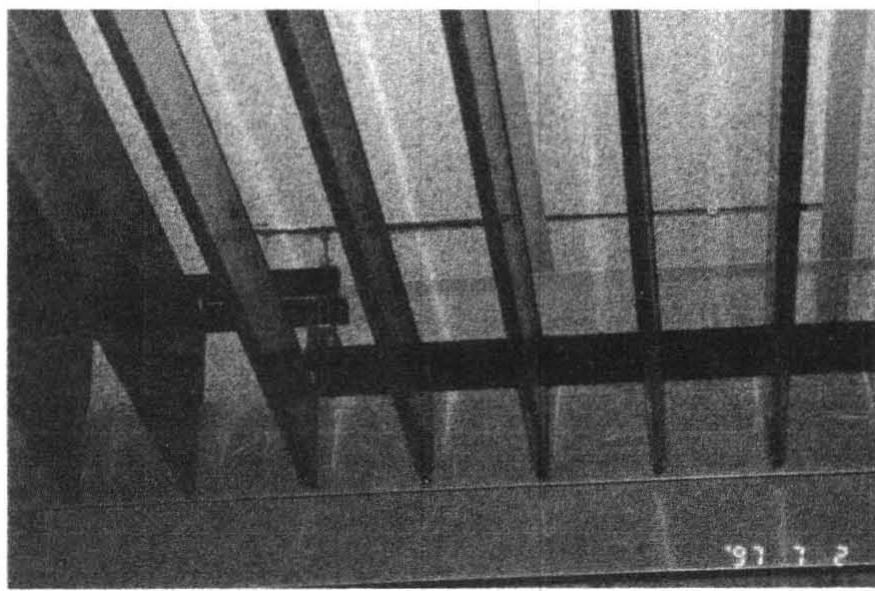

Fig. 11: Montagem do teto - Detalhe da fixação dos suportes dos baffles

vemos as dificuldades enfrentadas pela equipe de execução. Além de todos os problemas já relatados, para a colocação da camada de baffles, era necessário perfurar as placas de lã de vidro já colocadas, afim de atirantar os suportes dos baffles na laje. Isto danificava as placas e dificultava a fixação precisa dos suportes em uma determinada posição esperada em projeto.

\subsubsection{A Variação Constante dos Materiais Disponíveis no Mercado}

Alguns aspectos do projeto inicial foram reconcebidos em função do material especificado em projeto estar fora de linha ou ter sofrido alterações na época da construção do edifício, principalmente os materiais de acabamento. Dúvidas sobre a compra e a substituição de materiais foram assunto de grande parte das reuniões.

Há muito tempo o setor de construção civil sofre com a falta de padronização de medidas e com a irregularidade na disponibilidade dos materiais. Tradicionalmente, os cadernos de especificação definem um material "X ou similar", tentando contornar esta situação e dando margem à troca de materiais para a melhoria dos custos da obra. E é nesta similaridade que muitas vezes se perdem os objetivos que levaram a equipe de concepção especificarem determinado material.

Embora contraditório, na prática, dificilmente um material é descrito no caderno de especi- ficações através das características pelas quais foi especificado. Quase sempre ele é descrito pela tipologia, pelas dimensões, pelas cores, dentre outros, mas nem sempre são estas características que determinaram o seu uso.

Situações similares a estas são uma constante nas obras e demonstram a necessidade de um acompanhamento das implantações das soluções propostas no projeto, para que os ajustes não levem a modificações incoerentes com o resultado que se pretende alcançar.

No caso estudado, vimos, por exemplo, a necessidade de substituir o material do forro da sala por problemas de prazo para o fornecimento. A primeira proposta para substituição do material levava em conta as dimensões, a cor e o aspecto forro a ser substituído, mas não levava em conta os índices de absorção acústica que levaram a sua especificação. Durante uma reunião, o responsável pela compra dos materiais apresentou o problema e um material similar que deveria substituílo. Verificamos então que o segundo material não possuía as mesmas características acústicas do primeiro, embora tivesse o aspecto geral, dimensões e cores similares. Só após a compreensão do porquê tal material estava especificado e em que sua alteração refletiria nas condições de trabalho futuro é que o comprador ficou atento a esta característica.

Outro aspecto a ser considerado é a questão da padronização de medidas. No caso estudado, as 
chapas do piso elevado tinham uma dimensão diferente das chapas pretendidas como material de acabamento $\mathrm{e}$, caso este problema não houvesse sido antecipado nas reuniōes, as chapas de acabamento teriam que ser recortadas uma a uma na obra, provocando dificuldades de execução e possíveis atrasos. Inicialmente, sugeriu-se uma troca do material de acabamento para solucionar esta questão, mas verificamos que a característica do material que o levou a ser especificado era o fato de ser um material anti-estático. Assim, ambas as características precisavam ser observadas na substituição. Optou-se então por manter o material especificado inicialmente e negociou-se com fornecedor do piso elevado que as placas fossem entregues acabadas.

\subsubsection{As Indefinições no Plano de Organização do Trabalho e as Reestruturagöes Constantes da Empresa}

A globalização da economia, o contexto de competitividade e o atual momento da economia brasileira têm trazido repercussões importantes no interior das empresas, em especial, para o setor de petróleo que recentemente passou pela quebra do monopólio estatal.

Assim como muitas outras empresas brasileiras, a refinaria em questão encontrava-se em um momento de mudanças e adequações tecnológicas decorrentes da necessidade de tornar-se cada vez mais competitiva. Neste contexto, diversas iniciativas foram tomadas, como a centralização das salas de controle, sem que um plano de organização do trabalho de operação fosse completamente desenvolvido.

Indefinições organizacionais, como o número de operadores que iriam trabalhar na nova sala de controle e a polivalência entre eles, interferiram diretamente na definição do layout da sala e consequentemente nos projetos complementares originando alterações que se refletiram no andamento da obra.

A concepção de um meio de trabalho, seja ele um espaço, um equipamento ou um software, deve traduzir os conceitos e as características definidas na concepção organizacional da empresa. Isto significa que a organização do trabalho deve ser pensada com antecedência e que os meios de trabalho necessitam ser flexíveis o suficiente para incorporarem as evoluções que este plano organizacional certamente irá sofrer, como as inovações tecnológicas e as reestruturações internas.

No entanto, o que ocorre na maior parte dos casos é que a organização do trabalho não é pensada como um projeto que possui diferentes etapas (estudos preliminares, anteprojeto, detalhamento, ...), o que demonstra a pouca prioridade dada a esta dimensão. Um estudo adequado das reais necessidades da empresa e a definição de um plano de organização do trabalho deveriam ser um dos primeiros passos de um plano de modernização tecnológica, pois é aí que se definem as bases dos outros projetos necessários a esta modernização, sobretudo o projeto do espaço de trabalho (Duarte e Goldenstein, 1997).

Na prática, percebemos que somente depois da empresa investir em equipamentos e obras é que se pensa mais a fundo na organização do trabalho, ou seja, em como e com quem a futura instalação irá funcionar. Desta forma, dificilmente não haverão problemas, pois quando diversos aspectos já foram definidos e investimentos realizados, os limites para a adaptação do trabalho ao homem serão maiores.

Além de indefinições relativas à organização do trabalho dos operadores das equipes de turno (efetivos, repartição de funções) que se prolongaram até a fase final do projeto, nos deparamos, durante os dois anos de trabalho, com duas reestruturações organizacionais de grande impacto na empresa, que implicaram em troca de gerentes, chefes de projeto e composição de diversos setores da refinaria. Essas reestruturações organizacionais e os incentivos à aposentadoria com objetivo de redução de pessoal fizeram com que o setor de automação da empresa, responsável pelo projeto CIC, mudasse três vezes de che- 
fia, uma delas logo no início da etapa de construção.

Para se ter uma idéia das mudanças ocorridas, além da reestruturação de setores já mencionada, durante este período, algumas unidades deixaram de produzir e outras foram criadas. Como conseqüência houve mudanças em parâmetros importantes do projeto (características dos dispositivos de controle, reagrupamento das unidades em setores diferentes, previsão de novas unidades, número de consoles previstos e o seu compartilhamento, ...) que conduziram à alterações de layout da sala de controle, com reflexos diretos em outros projetos complementares (iluminação e acústica).

Nas últimas reuniões sobre o layout, já no final da obra, colocou-se em dúvida a ida da operação das unidades de produção de lubrificantes para o CIC, e embora houvessem sido feitas algumas sugestões para o arranjo dos consoles deste setor, a planta final apresentou somente um espaço de expansão disponível para as unidades, sem definição final da ocupação dos consoles.

\subsubsection{A Descontinuidade das Equipes Envolvidas na Análise, na Concepção e na Execução do Projeto}

Os itens abordados anteriormente apontam para a necessidade de se manter uma coerência de objetivos e compromissos entre as diversas etapas de projeto, apesar de cada etapa ter seus objetivos e compromissos próprios.

A lógica principal que orientou a concepção do projeto na maior parte das vezes não é passada à equipe de execução, e dificilmente está clara nos desenhos e na documentação que lhe é fornecida. Assim, desconhecendo os objetivos iniciais do projeto, a equipe de execução não pode se comprometer com eles e segue adotando a sua lógica própria.

Neste caso, como é comum em projetos de grande porte, o contrato com a empresa 2 , responsável pelo desenvolvimento do projeto, não se prolongou durante o período de execução da obra. A comunicação entre as equipes se tornou extremamente difícil, normalmente envolvendo custos de consultoria para que a empresa 2 voltasse a atuar durante a obra.

Considerando que a concepção de um projeto se dá desde a fase das análises iniciais de viabilidade, até o uso da edificação, onde os usuários se apropriam do seu espaço de trabalho, utilizandoos conforme suas necessidades e conveniências, e que em todas as etapas do projeto existe um certo grau de reconcepção por parte de quem realiza as atividades destas etapas, podemos dizer que a descontinuidade das equipes pode fazer com que a história do projeto se perca e com ela a sua coerência e os seus objetivos.

Em resumo, a incoerência entre o resultado final e o resultado esperado de um projeto se dá principalmente:

- Pela impossibilidade de se antecipar completamente o que vai acontecer nas etapas futuras do projeto durante a dita "etapa de concepção". Seja a nível de problemas intrínsecos ao desenvolvimento do projeto e da construção (detalhes, materiais,...); seja a nível das necessidades da empresa como um todo, que definem os dados de projeto; e

- Pela falta de negociação dos interesses dos diversos envolvidos no processo projetual que se guiam por lógicas próprias de cada grupo e de cada etapa e são premidos por condições diversas. Os conflitos gerados pelos choques de interesses são resolvidos normalmente pela decisão de quem "manda" naquela etapa, caso não haja uma estratégia de gerenciamento que permita a confrontação das idéias e as tomadas de decisão coletivas.

\section{A Negociação de Lógicas e Interesses nas Diversas Etapas do Projeto}

De forma semelhante ao acompanhamento da construção de uma residência para idosos analisa- 


\section{PRODUÇÃO}

do por Merin (1994), as reuniões de concepção e reconcepção do layout e do acompanhamento da obra do CIC se constituíram em espaços de tomadas de decisão coletivas apoiadas na discussão entre os participantes.

A diversidade de atores fez emergir diferentes lógicas e condicionantes que caracterizaram cada fase do projeto, que eram relacionadas principalmente:

- Ao tempo (prazo para término dos projetos e das obras);

- À coordenação do trabalho das diferentes equipes;

- Ao custo das alterações e ajustes necessários;

- À atividade de trabalho dos operadores de controle (as novas instalações deveriam possibilitar boas condições de trabalho);

- Às decisões tomadas nas etapas anteriores do projeto;

- À qualidade técnica do projeto (na etapa de concepção); e

- À durabilidade da obra e à confiabilidade das instalações (na etapa de execução).

As tomadas de decisão impunham aos diferentes atores uma negociação constante de suas prioridades, o que implicava em, de um lado, expor as suas condições e restrições e, de outro, conhecer e considerar as condições e restrições dos outros. Segundo Bucciarellli (1993), o processo de concepção é um processo de negociação e troca, e para assegurar a coerência da concepção os atores devem negociar as suas diferenças.

Num primeiro momento, as discussões entre os participantes das reuniões provocavam o encontro de diferentes lógicas de difícil compatibilização e de difícil solução satisfatória para todos. Por exemplo: Como esperar a entrega de um material importado (especificado para o forro), se o cronograma da obra já estava apertado? Como comprar o sistema de mascaramento eletrônico (projeto acústico), se a verba aprovada considerava o sistema de sonorização do caderno de especificações (mais simples e barato)? Como modificar o posicionamento e a quantidade de consoles, se as instalações já estavam prontas e os consoles encomendados? Enfim, cada grupo priorizava alguns aspectos do projeto durante as escolhas de soluções. Mas estas discussões foram extremamente produtivas.

Encontramos aqui algo semelhante ao que De Terssac (1993), em seu estudo sobre centros de decisões de um sistema produtivo, chamou de negociação de "contraintes". Segundo esse autor, as negociações eram possíveis uma vez que as contraintes não eram todas incontornáveis. Elas evoluíam em função do contexto e do tempo disponível.

Assim, as reuniões permitiram criar um ambiente de comunicação e colaboração entre os diversos envolvidos, o que na etapa de execução, foi decisivo para que a maior parte das dificuldades e problemas da obra fossem antecipados e resolvidos de forma a não se perder os critérios que direcionaram o projeto do CIC, dentre eles o de se construir um espaço adequado à atividade de operação futura.

Um dos papéis desenvolvidos pela equipe de ergonomia durante todo o projeto foi o de gerenciar estes encontros e a confrontação de diferentes lógicas. Cada participante destas reuniões trazia uma visão diferente dos problemas: a visão administrativa, a visão econômica, a visão técnica, a visão da operação, etc. Além destas lógicas particulares a cada participante, foi preciso gerenciar as lógicas do projeto, pois cada etapa é dominada por uma lógica própria.

Tomando por base a fase 1 da intervenção ergonômica, podemos dizer que uma das lógicas que regeu a etapa de concepção do CIC foi a lógica que priorizava as necessidades dos usuá-

6. Utilizamos o termo "contraintes", em francês, dado a dificuldade em traduzí-lo. A este termo pode ser atribuído, em função do contexto de sua utilização, significados próximos a: restriçōes, constrangimentos, condições, exigências. 
rios, introduzida a partir da análise ergonômica do trabalho e da participação dos operadores nas reuniões de concepção do espaço. Além dos interesses próprios, todas as equipes envolvidas na concepção do espaço buscavam conhecer e atender às necessidades dos usuários em atividade de operação, em vista da preocupação da refinaria com a confiabilidade do processo de produção. A grande dificuldade desta etapa foi, no entanto, fazer com que todas as equipes tivessem uma visão ampla e uniforme do que são estas necessidades. Caracterizar as necessidades do usuário do ponto de vista da atividade foi o principal papel da equipe de ergonomia neste momento.

As reuniões da fase 1, envolvendo engenheiros, operadores e ergonomistas, permitiram a negociação de lógicas baseadas no saber técnico dos engenheiros e no saber prático dos operadores, iniciando a construção técnica e social do projeto (Escouteloup et alli, 1995).

As reuniões da fase 2 tiveram as mesmas características das reuniões da fase 1 , mas acima de tudo evidenciaram um outro saber, o saber prático da execução da obra, necessário não só a construção, mas também à reconcepção do projeto.

Em relação a este tema, alguns aspectos das reuniões de acompanhamento de obra nos chamaram a atenção:

Uma das conseqüências da variabilidade das condições de trabalho inerente ao canteiro de obras foi fazer com que o engenheiro da obra se tornasse naturalmente um dos representantes da empresa 3 que mais participou das reuniões, já que era um dos poucos que estava na obra durante todo o processo, mantendo uma memória da história da obra, e ao mesmo tempo que tinha acesso aos problemas das diversas equipes subcontratadas.

Outro representante constante da empresa 3 nas reuniões foi o responsável pela compra de materiais, conseqüência direta da variação dos materiais disponíveis no mercado e da ausência do projeto executivo, o que gerava inúmeras dú- vidas na aquisição de materiais e na contratação de serviços.

Para a execução de soluções mais complexas, como por exemplo o teto, foi necessário a presença de projetistas (dos diversos projetos envolvidos), subcontratados para a montagem e fornecedores. As soluções dadas a partir da participação destes atores é que possibilitaram a execução dos detalhes de acordo com as premissas iniciais do projeto, mantendo as condições lumínicas e acústicas desejadas.

\section{Considerações Finais: Reflexões Sobre a Prática da Ergonomia em Projetos}

Pesquisas recentes na área de ergonomia alertam para o fato da concepção dos meios de trabalho envolverem diversos saberes, diversos atores, dentre eles o saber dos operadores. Daniellou (1994, p.28) identifica que há “uma diversidade de atores da concepção que não são somente os conceptores profissionais", se referindo a importância da participação dos empreendedores e dos usuários na construção dos objetivos e na avaliação das soluções do projeto. Ledoux (1994, p. 44) conclui que "o ergonomista não pode se limitar a se interessar pela atividade daqueles que são encarregados pela resolução ou materialização do projeto. Ele deve se interessar também pela atividade de elaboração do projeto pelos que não concebem" para se referir as definições de projeto que se originam nas decisões dos empreendedores, nas normas e legislações específicas de cada caso e nas limitações impostas por organismos financiadores. Garrigou et alli (1995) descrevem o "projeto participativo", onde se formam grupos multidisciplinares de projeto.

No momento atual, a participação da ergonomia em projetos tem exigido dos ergonomistas uma prática que vai além dos diagnósticos das condições de trabalho e das recomendações para 
sua transformação. Ao participar do projeto desde suas fases iniciais, o ergonomista é também chamado a construir soluções. Construir soluções implica não só em uma participação efetiva na etapa de concepção, mas também no acompanhamento da implantação das soluções sugeridas, para que se chegue de fato a uma realidade de trabalho próxima à que se aspirou.

A partir da experiência do Projeto CIC, surgem algumas questões a serem desenvolvidas e aprofundadas.

Em relação à fase inicial do projeto, a etapa de concepção, caberia nos perguntar: Quem representa o saber prático da execução da obra neste quadro de atores da concepção?

A princípio, nos parece que este saber não é claramente representado nesta etapa. Alguns aspectos da prática de execução de obras podem ser levados em conta, dependendo da experiência que arquitetos e engenheiros envolvidos na concepção tenham com o canteiro de obras. Mas está longe de representar as contraintes da etapa de execução.

Representar o saber prático da execução da obra e a lógica que prioriza o atendimento a custos/prazos pré-determinados aliados à qualidade técnica (que se destaca e direciona a etapa executiva), na etapa inicial da concepção, poderia gerar dois resultados, a princípio:

- Evitar uma parte das adaptações que são feitas durante a obra com margens de manobra extremamente limitadas, devido à desconsideração das "contraintes" da construção; e

- Permitir que a lógica de atendimento às necessidades do usuário se estendesse para a etapa executiva pois, além de ter a oportunidade de participar das negociações colocando o seu ponto de vista, a equipe de execução conheceria e compreenderia o porquê das soluções adotadas.

Embora a engenharia simultânea já aponte para este caminho, a principal dificuldade para se colocar esta idéia em prática na concepção dos espaços de trabalho é o atual esquema de contratação de equipes durante um projeto de construção civil. As concorrências para projetos de grande porte ocorrem a cada etapa do projeto, reforçando o distanciamento entre a concepção e a execução, e dificultando a escolha de representantes da equipe que realmente vai executar a obra.

Temos, no entanto, os exemplos de intervenções ergonômicas que adotaram práticas específicas que buscam contornar as dificuldades de se antecipar o futuro pela ausência de dados concretos no presente. Por exemplo: em situações de instalações totalmente novas já houveram experiências com uso de situações de referência para representar o saber de operação e configurar possíveis cenários, visto não existirem situações "concretas" para observar e as equipes reais de operação ainda não estarem contratadas. Esta prática ainda não foi experimentada em relação ao saber de execução no contexto da construção civil, mas o mesmo princípio poderia ser aplicado, possivelmente com uma outra metodologia. Uma possibilidade que se apresenta viável são as reuniões de projeto como espaço para confrontação de lógicas e tomadas de decisão coletivas.

Como dado de referência, a nossa experiência profissional mostra que em projetos de pequeno porte, conduzidos do início ao fim por uma equipe básica que projeta e constrói (empresas de pequeno a médio porte que possuem equipes de projeto e de execução razoavelmente constantes e integradas), o grau de dificuldade e o volume da reconcepção durante a execução são bem menores e a história do projeto naturalmente se mantém de forma mais coerente durante todo o processo.

Em relação a atuação da equipe de ergonomia na fase 2 do projeto, podemos caracterizá-la por três funções principais:

- O gerenciamento das reunióes e da confrontação das diferentes lógicas e interesses das equipes envolvidas com a obra e com a modificação do layout, de forma similar ao que foi realizado na fase 1. 
- A caracterização das necessidades do usuário do ponto de vista da atividade, integrando as características do trabalho efetivamente realizado pelos operadores e construindo uma representação compartilhada do trabalho futuro e das conseqüências de detalhes técnicos sobre a atividade - o que foi feito com base no conhecimento adquirido especialmente pela análise da atividade, pelo estudo do contexto e das situações de trabalho que os operadores enfrentam no seu dia-a-dia.

- A representação do saber da equipe de concepção na proposta de soluções durante as reuniões de obra, papel este dividido com engenheiros do setor de automação e de fiscalização da refinaria que participaram da concepção do projeto.

Em relação à primeira função citada, podemos dizer que o gerenciamento das reuniões de trabalho tem sido um papel constante das equipes de ergonomia envolvidas com projetos. A dinâmica participativa adotada nesta proposta, assim como a construção estratégica e social da intervenção (Escouteloup et alli, 1995), asseguram aos ergonomistas uma posição de interlocutor direto e aceitável para as diversas equipes envolvidas em cada etapa do projeto, o que o transforma em um facilitador da comunicação entre as equipes. Esta atuação da equipe de ergonomia acabou por influenciar fortemente toda a gestão do projeto, que estava a cargo do setor de automação da refinaria. A gestão do projeto se apoiou constantemente nas informações e resultados das reuniões promovidas pela equipe de ergonomia, tanto nos assuntos relativos à obra quanto nos relativos à reformulação do layout.

A caracterização das necessidades dos usuários do ponto de vista da atividade também é função dos ergonomistas já descrita em várias intervenções na etapa de concepção de um projeto. No caso do CIC, ela se estendeu à etapa construtiva, visto que esta é marcada pela reconcepção do projeto. Sob este aspecto, concordamos com Escouteloup et alli (1995) que afirma que a construção técnica da intervenção ergonômica permi- te aos ergonomistas acumular rapidamente informações sobre a atividade em situações existentes que irão instruir as demais equipes sobre as conseqüências prováveis de determinadas escolhas sob o ponto de vista da eficácia do sistema e da saúde dos trabalhadores, o que influencia as tomadas de decisão.

O terceiro papel desempenhado pela equipe de ergonomia foi o de assumir em determinados momentos a função de conceber, de projetar. No nosso entender, isto se deu principalmente por dois motivos:

Primeiro, pela participação da equipe de ergonomia na etapa de concepção, sugerindo mudanças nos anteprojetos a nível de estudos preliminares, ou seja, propondo soluções, o que a faz pertencer à equipe inicial de concepção não só como base de informações sobre a atividade e sobre o funcionamento do homem no trabalho, mas também como projetista. Assim, durante a obra, as demais equipes esperavam da equipe de ergonomia uma atuação a nível de projeto, de soluções para a obra e para o layout. Isto foi possível em decorrência de todas as informações acumuladas sobre a atividade, dos dados levantados e discutidos nas reuniões e do conhecimento técnico e experiência prática dos integrantes da equipe (formação básica em engenharia e arquitetura).

Um segundo motivo para este tipo de atuação seria a ausência dos projetistas da empresa 3 durante a etapa de execução. O que levou os outros participantes da etapa anterior (ergonomistas e engenheiros dos setores de automação e físcalização) a tentar manter a história do projeto e a coerência entre as mudanças necessárias e as premissas adotadas na concepção.

Neste caso, isto foi possível porque houve a presença contínua de algumas pessoas durante as duas etapas (concepção e execução). Era a partir do seu conhecimento sobre a história do projeto e dos porquês de determinadas escolhas é que se podia confrontar as diversas alternativas que se apresentavam durante a obra com as premissas 
iniciais do projeto.

Concluímos então, que a atuação essencial do ergonomista na etapa de construção se inscreve, acima de tudo, num contexto de negociação com fortes restrições e implica em uma necessidade de revisão constante de posições. Esta atuação pode facilitar a construção de compromissos entre os diferentes atores, na medida que se consegue construir uma representação compartilhada do trabalho futuro e das conseqüências de detalhes técnicos sobre a atividade.

A antecipação aos problemas, a confrontação das diferentes lógicas e o tempo disponível são essenciais para a criação de soluções originais. A interação entre as equipes durante a execução da obra, promovida nas reuniões, pode ser uma das formas de se ocupar a lacuna entre as recomendações e o resultado final de um projeto ergonômico.

Por outro lado, a formação dos ergonomistas brasileiros através de cursos de pós-graduação em engenharia, em especial a engenharia de produção, facilitam a sua inserção em projetos não só como instrutores sobre conteúdo do trabalho, mas também como projetistas de novos meios de trabalho, o que os fazem acumular as funções de conceber e projetar, um viés novo, a ser considerado.

\section{Bibliografia}

BÉGUIN, P. E BERGAMINI, J. F. Organiser la Conception pour le Chantier. In: Intervenir par l'Ergonomie - Regards, Diagnostics et Actions de l’Ergonomie Contemporaine - Actes du XXXIème Congrès de la Société d'Ergonomie de Langue Française. Bruxelas, Bélgica, 1996, v. 1, p. 219 223.

BUCCIARELLI L. L. Designing Engineers. MIT Press, Massachusetts, 1993.

DANIELlOU, F. Le Statut de la Pratique et des Connaissances dnas L'Intervention Ergonomique de Conception. Thèse d'Habilitation à
Diriger des Recherches. Toulouse, Université de Toulouse - LeMirail, 1992.

DANIELLOU, F. L'Ergonome et les Acteurs de la Conception. In: Actes du XXIXème Congrès de la Société d'Ergonomie de Langue Française. Eyrolles, Paris, 1994, p. 27 - 32.

DE TERSSAC G. ET ALII. La Renégociation des Contraintes. In: Actes du Colloque d'Ergonomie, CNRS, Toulouse, 1993.

DUARTE, F. A Análise Ergonômica do Trabalho e a Determinação de Efetivos: Estudo da Modernização Tecnológica de uma Refinaria de Petróleo no Brasil. Tese de Doutorado, Rio de Janeiro PEP/COPPE/UFRJ, 1994.

DUARTE, F E GOLDENSTEIN, M. The Layout as an Image of Work Organization. In: From Experience to Innovation - Proceedings of the $13^{\text {th }}$ Triennial Congress of the International Ergonomics Association. Tampere, Finlândia, 1997, p. 95-97.

ESCOUTELOUP, J., MARTIN, C, \& DANIELLOU, F. L'Ergonome et la Maîtrise D'Ouvrage. In: Performances Humaines \& Techniques. Toulouse: 1995, nov./déc., n 79, p. 18 - 20.

GARRIGOU, A., DANIELLOU, F., CARBALLEDA, G. \& RUAUD, S. Activity Analysis in Participatory Design and Analysis of Participatory Design Activity. In: International Journal of Industry Ergonomics. 1995, n. 15, p. 311 - 327. GOLDENSTEIN, M. Desvendar e Conceber a Organização do Trabalho: Uma Contribuição da Ergonomia para o Projeto de Modernização de uma Refinaria de Petróleo. Tese de Mestrado. Rio de Janeiro, PEP/COPPE/UFRJ, 1997.

GUERIN, F.; LAVILLE, A.; DANIELLOU, F.; DURAFFOURG, J. E KERGUELEN, A. Comprendre le Travail pour le Transformer: La Pratique de l'Ergonomie. Montrouge: ANACT, 1991.

JONG, A. M.; WITTEVEEN, J. ; MAAS G. J. E SCHAEFER, W. F. The Process of Implementing Ergonomic Innovations at Building Sites. In: From Experience to Innovation Proceedings of the $13^{\text {th }}$ Triennial Congress of the 
International Ergonomics Association. Tampere, Projet de Conception Arquiteturale. Une Finlândia, 1997, v.6, p. 87 - 89.

Diversité d'Acteurs: La Place de l'Ergonome

LEDOUX, E. La Conception Architecturale: Qui Sont les Concepteurs? In: Actes des Journées de Bordeaux sur la Pratique de L'Ergonomie. Bordeaux: Université de Bordeaux II, 1994, p. 41-45.

LIMA, D. L. M. Interaçōes na Construção da Ação Ergonômica. Tese de Mestrado, PEP, COPPE, UFRJ. Rio de Janeiro, 1999.

MALINE, J. Simuler le Travail: Une Aide à la Conduite de Projet. Edições ANACT, Montrouge, 1997.

MARTIN, C.; ESCOUTELOUP, J. E DANIELLOU, F. L'Ergonome et la Programation Architecturale. In: Performances Humaines \& Techniques. Toulouse, novembre - décembre $1997, \mathrm{n}^{\circ} 79$, p. $23-28$.

MERIN, S. La Phase de Chantier dans un

dans la Negociations de Contraintes. Memoire de DESS Laboratoire de Ergonomie des Systèmes Complexes, Université des Bourdeaus II, França, 1994.

SANTOS, P. A Ergonomia no Projeto de Telas com Sistema Digital de Controle Distribuido - SDCD: Da Concepção de Interfaces às Situações de Ação. Tese de Mestrado. Rio de Janeiro, PEP/COPPE/UFRJ, 1998.

SIX, F. Quelques Aspects du Travail du Chef de Chantier du Bâtiment. In: Actes des Journées de Bordeaux sur la Pratique de l'Ergonomie. Laboratoire d'Ergonomie des Systèmes Complexes, Université Bodeaux 2, 1994, p. 89 - 95.

WISNER, A. Por Dentro do Trabalho: Ergonomia, Método e Técnica. São Paulo, FTD Oboré, 1988. 